\title{
THE EFFECTIVENESS OF CONTENT-BASED INSTRUCTION TO TEACH SPEAKING VIEWED FROM STUDENTS' CREATIVITY
}

\author{
Aisyah Sunarwan \\ Muhammadiyah Universiti of Metro \\ aisyahsunarwan@gmail.com
}

\begin{abstract}
The objectives of the research are to examine: (1) whether Content-Based Instruction is more effective than Audio-Lingual Method to teach speaking to the third semester students of STAIN Jurai Siwo Metro in the academic year of 2012/2013; (2) whether the students having high creativity have better speaking skill than those having low creativity; and (3) whether there is an interaction between teaching methods and students' creativity in teaching speaking. The method in this research was experimental study. It was conducted at the third semester students of STAIN Jurai Siwo Metro in the academic year of 2012/2013. The sample of the research was two classes; C consists of 40 students as an experimental class and $\mathrm{E}$ consists of 40 students as a control class. The sampling technique used was cluster random sampling. Each class was divided into two groups (the students having high and low creativity). The techniques of collecting data were creativity test and speaking test that were tried out to know their readability. The data were analyzed by using Multifactor Analysis of Variance (ANOVA) test of $2 \times 2$ and Tukey test. The result of data analysis shows that: (1) Content-Based Instruction is more effective than Audio-Lingual Method to teach speaking (2) the students having high creativity have better speaking skill than the students having low creativity and (3) there is an interaction between teaching methods and students' creativity in teaching speaking. Based on the finding, it can be concluded that Content-Based Instruction is an effective method to teach speaking.
\end{abstract}

Keywords: Content-Based Instruction, Audio-Lingual Method, Speaking, Creativity.

\section{Introduction}

According to Harmer (2009: 76), a language function is the purpose you wish to achieve when you say or write something. More than one and a half billion native and nonnative speakers use English all around the world as a first, second, or foreign language. Today English is used in education, international trade, tourism to international media, airtraffic control, and technology. All these suggest that English has become an international language that is used for communication among different notion and culture. Because communication is very important for our life, it is needed to teach to the students in order they are able to communicate using good English with a correct pronunciation.

There are four skills in English, they are listening, speaking, reading, and writing. These four skills are regarded as the serious problem for them. Among these four skills, speaking is one of the skills that should be taught intensively, since this skill is considered as a more important skill than other skills.

In university, especially in STAIN Jurai Siwo Metro, speaking is one of the compulsory subjects that must be mastered. This subject is learned in four semesters, from speaking 1 until speaking 4. It is very important because it can develop the students' skill as the thinking human being.

In accordance with that condition, speaking skill is very important to help the students improve their speaking skill, know the message and understand what other people are saying to measure their skill. Furthermore, by speaking the students can also develop their idea and express it orally and they can enlarge their vocabulary mastery.

The ability to speak a second or foreign language well is extremely vital for university students. A teaching learning 
process is said to be successful when there

Teacher should always motivate the students and must be creative in creating enjoyable atmosphere that can stimulate the students to speak. In such condition, there will not be more students who think that English is so hard to study, especially for those who have low creativity, they will enjoy with speaking class, because it is fun and interesting.

Furthermore, the fact shows that many students are less interested in speaking. The speaking skill of the students is still low, unsatisfying, and still far from the expectations. It is caused by their low learning motivation and interest; they also have low creativity because the techniques and methods used by the teacher are not appropriate for the students; they can't answer the teacher's question orally; lack of vocabulary mastery, in addition, they can't express their ideas using appropriate vocabulary and correct grammatical forms; and most of them mispronounce the words.

The students' low creativity must be dealing with the teaching and learning process and considering the phenomenon above, To help the teachers in teaching speaking to university students, teachers may use an interesting method. One of alternative methods is Content-Based Instruction which is suggested to be applied in teaching speaking. CBI is effective to teach English as a second language because with CBI, students can develop their language skills as well as gain access to new concepts through meaningful content.

Kranche in Richard (2005: 204) states that $\mathrm{CBI}$ is the teaching of content or information in the language being learned with little or no direct or explicit effort to teach the language itself separately from the content being taught. Content refers to the information or subject matter that we learn or communicate through language rather than the language used to convey it is students' involvement in the activity. (Richard, 2006: 28). Content has also become popular one both within language teaching and in the popular media. In other words, content is meant as the use of subject matter as a vehicle for second or foreign language teaching or learning.

Therefore, in CBI, the content plays the important role, and language is used to communicate meaning. The language teaching focuses on how information and meaning from meaningful content are utilized in discourse or texts, not in a single sentences. The students learn through doing and are actively engaged in the learning process. They don't depend on the teacher to direct all learning or to be the source of all information, they can learn through peer input and interaction. Skills of the target language are not separated from each other, and they together are involved in all activities, so that, they will assume active, social roles in the classroom, and involve interactive learning, negotiation, information gathering, and the co-construction of meaning. Authentic and meaningful contents will motivate the students to make greater connections between topics, elaborations with learning material, and can recall information better.

Meanwhile, Audio-lingual method is defined as a method which emphasizes on repetition of the words to help the students to be able to use the target language communicatively. The purpose of the repetition/drills is to breakdown some sentences into smaller part. According to Moultan, as quoted by Nagaraj (1996: 79) five slogans which form the basis of Audio-lingual Methods are as follows: (a) Language is speech, not writing; (b) A language is set of habits; (c) teach the language, not about the language; (d) A language is what native speakers say, not what someone thinks they ought to say; and (e) Languages are different. As the writer has mentioned in the previous 
paragraph, one of the methods that can be used to teach speaking is audio-lingual method.

The goal of Audio-lingual Method is to use the target language communicatively and the drill must be suitable for teaching speaking. Therefore, students need to learn more and use it without stopping by forming new habits of their native language. In short, drilling as part of audio-lingual method has been used in teaching speaking.

In addition, both method will be applied successfully in teaching speaking if they are supported by the students' creativity because without creativity in speaking students will be passive. In education, creativity is the most important source of activities or experience. In other way, we can say that when students are interested in the activity, they will do it with their pleasure, they will get the satisfaction from it and of course they will be very responsible for the things they have and do. In addition, the learners will be interested in English when the learning activities or methods applied by the teachers are appropriate, interesting, and challenging. This research was aimed at finding out (1) whether content-based instruction is more effective than audiolingual method to teach speaking for the third semester students of STAIN Jurai Siwo Metro; (2) whether the students having high creativity have better speaking ability than those having low creativity for the third semester students of STAIN Jurai Siwo Metro; and (3) whether there is an interaction between the teaching methods and students' creativity.

Speaking is one of the four skills. Brown (2001: 257) states that speaking is literally defined as to say things, express thought aloud, and use the voice. Furthermore Bailey (2005: 2) also defines speaking as a productive skill, which consists of producing systematic verbal utterances to convey meaning. It means that, speaking is an activity including two persons, the speaker and the listener, and also other people both individual and group who conduct communication in our life.

Content-based Instruction (CBI) is defined as the teaching of content or information in the language being learned with little or no direct or explicit effort to teach the language itself separately from the content being taught (Kranche, as cited in Richard and Rodgers, 2001: 204). This teaching is considered by many researchers as an effective and realistic teaching method in terms of combining language and content learning.

Audio-lingual method is a style of teaching foreign languages. It is based on behaviorist theory. Brown (2007: 111) states that behavioristic psychologist advocated conditioning and habit formation models of learning. Behaviourisms is a philosophy of psychology based on the proposition that all things which organisms do including acting, thinking, and feeling.

Creativity is the generation of imaginative new ideas, involving a radical newness innovation or solution to a problem, and radical reformulation of problems (Newel and Shaw 1972 in Safertzi 2002: 2). Furthermore, they explain that creativity involves the generation of new ideas or recombination of known elements into something new, providing valuable solutions to a problem.

In this research, the researcher proposes some hypothesis as follows: (1) Content-based Instruction is more effective than Audio-lingual Method to teach speaking for the third semester students of STAIN Metro; (2) The students having high creativity have better speaking skill than those having low creativity for the third semester students of STAIN Metro; and (3) There is an interaction between the teaching methods 
and students' creativity for teaching speaking.

\section{Research Methodology}

In this research, the method applied is experimental research. An experimental research is the research where the researcher can manipulate one or more variables and controls any changes in other variables. The purpose of experimental research is to determine cause-and-effect relationships (Johnson and Christensen (2000: 23). The writer chose the experimental research because the research is related to the effectiveness of teaching methods used as the independent variables and creativity as the control variable in teaching speaking skill for the third semester students of STAIN Metro. This research involves three kinds of variables namely independent variable, dependent variable, and attribute variable. The independent variable of this research is the teaching methods. The teaching methods used in this study are contentbased instruction and audio-lingual method. In this way, content-based instruction group of students function as experimental group and Audio-lingual group of students function as control group. Furthermore, the dependent variable of this research was students' speaking skill of the third semester students of STAIN in the academic year of $2012 / 2013$. The attribute variable of this research was students' creativity in learning. In this study the writer was interested in investigating the effect of independent variable (X) or teaching methods on dependent variable $(\mathrm{Y})$ or speaking skill, in which the relationship between $\mathrm{X}$ and $\mathrm{Y}$ is changed by the attribute independent variable (Z) or students'creativity. This study was conducted at the third semester students of STAIN Metro in the academic year of $2012 / 2013$. The research was conducted in July 2012 up to March 2013. A population is a set (or collection) of all elements processing one or more attributes of interest (Arikunto, 2007: 130). Furthermore, Gay (1992: 125) states that population is the group of interest to the searcher, the group to which she or he would like the results of the study to be generalized. Based on the above definitions, population is the whole subjects that are going to be investigated. In this research, the target population of this study was all of the third semester students of STAIN Metro in the academic year 2012/2013. The third semester students of STAIN Metro were divided into five classes, those are A, B, C, D, and E which consisted of 200 students and each class consisted of 40 students. Sample is a number of individuals for a study in such a way that the individuals represent the larger group from which they are selected (Gay, 1992: 125). Meanwhile, Sugiyono (2010: 81) adds that sample is a part of such characteristics in the population. Johnson and Christensen (2000:158) defines sample as a set of elements taken from a larger population according to a certain rules. Furthermore, they state that a sample is always smaller than a population, and it is often much smaller. Based on the theories, the writer took only 80 students or two classes from all of population as the sample of this study. Johnson and Christensen, (2000:156) say that sampling is the process of drawing sample from a population. Furthermore, Gay (1992: 140) also states that sampling is the process of selecting a number of individuals for a study in such a way that the individuals represent the larger group from which they are selected. In this research, the writer used the cluster random sampling. Cluster sampling is a sampling in which groups, not individuals, are randomly selected (Gay, 1992: 132). In this point, the selected group of all members are those who have similar characteristic. To 
determine which class would be the experimental group and the control group, the writer took the class randomly by lottery. The experimental group that was chosen would be given a treatment by using content-based instruction. On the other hand, the control group was taught by using Audio-lingual method. Among the five classes, the writer decided to take only two classes as the sample of the study, which consists of 80 students. In order to get the data the students' speaking skill, the reseacher gave them a speaking test. The test was used to know the students' speaking skill after being given treatment. The writer administered the steps as follows: (1) the writer gave the certain topic; (2) the students were given 20 minutes to prepare to make a dialogue; (3) the students performed the dialogue in pairs; (4) the students' dialogue was recorded and scored by two scorers, researcher and other person who understand how to score speaking. It is assumed that the score can be more objective. In this test, the writer assessed the readability of test instruction to know whether the test instructions are readable for the students. Dale and Chall (1949: 23) define the readability as the sum total (including the interactions) of all those elements within a given piece of printed material that affects the success a group of readers have with it. Furthermore, DuBay (2004: 3) defines readibility as the ease of understanding or comprehension due to the style of writing. The test can be said that it is successful if the students can understand it, read it at an optimum speed, and find it interesting. In other word, the instruction of the speaking test should be clear and easy to understand. It is essential that the writer obtains feedback to check that the test instructions have been understood before the test is used in this research, it was tried out to 40 students. The result of the try out showed that the test instruction was clear for the students to understand.

In this research, creativity test was provided in written form with 30 items. There were six indicators, each consists of 5 items. This test was tried out to 40 students. In giving a test of creativity, it is important to set and determine an understandable instruction. It is needed because there are some cases in which the students failed to do the test due to their inability to understand the instruction. To know the readibility of creativity test, the researcher asked the students who were not from the member of experiment and control group to read and understand the creativity test. If the students can understand about the instruction from the test, it means that the test is understandable. By checking the readibility of the test, the researcher knew whether the content was too simple or too complex for the readers. The technique used in analyzing the data of this study was descriptive and inferential analysis. Descriptive analysis was used to know the mean, median, mode, and standard deviation of students' scores in speaking. In this study the researcher applied multifactor analysis of variance (ANOVA).

The Design of $2 \times 2$ ANOVA

\begin{tabular}{|c|c|c|}
\hline $\begin{array}{l}\text { Teaching } \\
\text { Methods } \\
\text { Creativity }\end{array}$ & $\begin{array}{c}\text { Content- } \\
\text { Based } \\
\text { Instruction } \\
\mathrm{A}_{1}\end{array}$ & $\begin{array}{l}\text { Audio-lingual } \\
\text { Method } \\
\mathrm{A}_{2}\end{array}$ \\
\hline $\begin{array}{c}\text { High } \\
\text { Creativity } \\
\left(\mathrm{B}_{1}\right)\end{array}$ & $\begin{array}{c}\text { First group } \\
\text { Students } \\
\left(A_{1} B_{1}\right)\end{array}$ & $\begin{array}{c}\text { Second group } \\
\text { Students } \\
\left(A_{2} B_{1}\right)\end{array}$ \\
\hline $\begin{array}{c}\text { Low } \\
\text { Creativity } \\
\left(\mathrm{B}_{2}\right)\end{array}$ & $\begin{array}{c}\text { Third group } \\
\text { Students } \\
\left(A_{1} B_{2}\right)\end{array}$ & $\begin{array}{c}\text { Fourth group } \\
\text { Students } \\
\left(A_{2} B_{2}\right)\end{array}$ \\
\hline
\end{tabular}

Then, Tukey test was used to know the difference between teaching methods and the mean score obtained is used to know which method is more effective to teach 
speaking, whether Content-based Instruction or Audio-lingual method.

\section{Result And Discussion}

Based on the result of analysis, it was found that the data of $\mathrm{A}_{1}$ shows that the score is 53 up to 83 . The mean is 70.98 , the mode is 77.28 , the median is 72.83 and the standard deviation is 8.798 , the data of $\mathrm{A}_{2}$ shows that the score is 55 up to 80. The mean is 67.4 , the mode is 64.5 , the median is 67.00 , and the standard deviation is 7.712 , the data of $B_{1}$ shows that the score is 55 up to 83 . The mean is 75.75 , the mode is 77 , the median is 72 , and the standard deviation is 8.605 , the data of $\mathrm{B}_{2}$ shows that the score is 53 up to 80. The mean is 67.5 , the mode is 70.0 , the median is 68.00 , and the standard deviation is 7.511 , the data of $A_{1} B_{1}$ shows that the score is 65 up to 83 . The mean is 77.1 , the mode is 81.70 , the median is 77.50 , and the standard deviation is 5.236 , the data of $\mathrm{A}_{2} \mathrm{~B}_{1}$ shows that the score is 55 up to 78 . The mean is 64.5 , the mode is 58.79 , the median is 63.50 , and the standard deviation is 6.786, the data of $\mathrm{A}_{1}$ $B_{2}$ shows that the score is 53 up to 75 . The mean is 64.8, the mode is 69.17, the median is 65.00 and the standard deviation is 6.973, and the data of $\mathrm{A}_{2} \mathrm{~B}_{2}$ shows that the score is 58 up to 80 . The mean is 70.3 , the mode is 70.83 , the median is 70.50, and the standard deviation is 7.159. It was also found that the data was normal because $\mathrm{L}_{\mathrm{o}}$ (L obtained) is lower than $\mathrm{L}_{\mathrm{t}}(\mathrm{L}$ table) at the level of significance $\alpha=0.05$. L stands for Lilliefors and the data was homogenous because $\chi_{0}^{2}(4.00)$ is lower than $\chi_{t}$ at the level of significance $\alpha=5 \%$ (7.81). So $\chi_{0}^{2}$ $<\chi_{\mathrm{t}}(4.00<7.81)$. Furthermore, based on the result analysis by using $2 \times 2$ ANOVA and Tukey test, it was found that $\mathrm{H}_{\mathrm{o}}$ was rejected because $F_{o}>F_{t} .\left(F_{o}\right.$ is higher than $F_{t}$ ) and there was a significant difference between the two groups (Group A and group B).
Based on the result above, it can be stated that (1) Content-based Instruction is more effective than Audio-lingual Method in teaching speaking. Content based instruction (CBI) is a teaching method that emphasizes on content. Content here is related to the information or subject matter that is learned through language rather than language to convey it. The focus of a CBI lesson is on the topic or subject matter. It is one of the ways that can be used to improve students' speaking skill because it deals with the study that focuses on content. Krahnke in Richard (2005: 204) states that CBI is the teaching of content or information in the language being learned with little or no direct or explicit effort to teach the language itself separately from the content being taught. Furthermore, Richard (2006: 28) emphasizes content refers to the information or subject matter that we learn or communicate through language rather than the language use to convey it. In content-based instruction students can acquire the content area with a subject matter comprehensibly and simultaneously can increase their language skill. The teacher has to fulfill several roles, such as being a good language teacher and in addition having an appropriate knowledge of the subject matter. First of all, teachers can and should use authentic materials such as newspaper articles and advertisements (Richards \& Rodgers 2001: 213-214). In addition, the teacher has to choose material. If the material is not suitable enough, he has to adapt it to the learners' language level. Audio-lingual method is a method of teaching speaking which focuses on accuracy through drills and dialogues that are formed to be grammatically correct. The learning process emphasizes active and simple practice rather than intellectual analysis. The specific learning methods employed by Audio-lingual method are 
memorization of dialogues, imitative repetition and pattern drills. It is supported by Brooks (in Richard 2001: 59) Recognition and discrimination are followed by imitation, repetition, and memorization. It uses dialogues as the main form of language presentation and drills as the main training methods. It is the behaviouristic theory that learn how to use the target language automatically. The new material in this method is presented in the dialogue form with the structural patterns taught by using repetitive drills. According to Richards, etal. (1986), Drills and pattern practice of the Audio-lingual method include: (1) Repetition: where the student repeats an utterance as soon as he hears it; (2) Inflection: Where one word in a sentence appears in another form when repeated; (3) Replacement: Where one word is replaced by another; and (4) Restatement: The student re-phrases an utterance. If there is an error done by students, it will be directly corrected. The students are also not allowed to use their mother tongue during the learning process. They have to speak in English and they have to imitate and repeat what is said by the teacher. The intention is to make language learning less of a mental burden and more a matter of effortless and frequent repetition and imitation. As Audio-lingual continues to be used, it also continues to gain criticism, as Jeremy Harmer (2001: 79) notes, "Audio-lingual methodology seems to banish all forms of language processing that help students sort out new language information in their own minds." As this type of lesson is very teacher centered, the students can't do something without the instruction from the teacher. That is why this Contentbased Instruction method is more effective than Audio-lingual method to teach speaking. (2) The students having high creativity have better speaking ability than those having low creativity. It is essentially important for students having high creativity because if they are creative they will be able to explore their creativity with the way they have in joining the teaching learning process. Creative students are remarkably able to adapt themselves in any situation or condition to achieve their ambition. They also have brilliant ideas or concepts to create something and have a great deal of physical energy in learning. They study and work long hours to create the production of novel and develop their ideas with great concentration and enthusiasm only to get what they want. Amabile (1996: 1) states that high creativity student is good at the production of novel and useful ideas in any domain. In order to be more creative, a product or an idea must be different from what has been done before. Furthermore, Atwater (1990: 155) states that students having high level of creativity expect to do well in thir accomplishments and try to be successful. In this case, the students explore their ability to create some new words given based on the initial of word, find out some words based on the letters in one word provided, construct a word based on the first letter of every words in a sentence provided, find out an object that has double characteristics, find out the unusual usage of the daily things, and the ability to find out the effect of the event. Creativity is very important for students because it is related to how the students' imagination is and how they use their creativity to recreate and reproduce things with the process viewed from students' fluency and originality in thinking in their life. In contrast, the students' having low creativity have the opposite characteristics. they tend to be passive in joining the class. They are shy to do something because they are afraid of making mistakes. They don't have innovation to make something different they do something monotonously, and they can't develop their idea. They don't 
know what to do because they have no inspiration. The students who have low creativity have less activity. They wait for their friends action and then follow it. They will also keep silent without talking anything even when the teacher asks the students to do something. The problems mentioned above are because the students are not focus in what they do. Guest (1984: 4) states that students with low creativity underestimate their worth, think less of themselves than they should, and focus on their weaknesses. In addition, McGhee (in Sefertzi 2000: 21) confirms that Most people think less creatively when they're not so seriously and intently focused on the task. The problem in most cases today is that the pressure is always on. They need more attention that is the reason why the teacher should treat them by controlling intensively during the class, so the students will enjoy the teaching and learning process. That is why the students who have high creativity have better speaking ability than those who have low creativity because without creativity, mankind would not progress, (3) There is an interaction between methods and students' creativity in teaching speaking. Applying a good method to teach speaking is the success of learning. One of the methods used to teach speaking is Content-based Instruction. Content-based Instruction is the teaching of content or information in the language being learned with little or no direct or explicit effort to teach the language itself separately from the content. Content here is meant as the use of subject matter as a vehicle for second language teaching or learning. It is supported by Richard (2001: 204) content is used with a variety of different meanings that refers to the substance or subject matter that we learn or communicate through language rather than the language used to convey it. It is believed that it is good because it provides natural context for using the target language in the classroom in which the focus of learning is in the content of what is being taught, so students can acquire the content area with a subject matter applied in learning process. They can also explore their speaking skill because they have many opportunities to express their ability. The students having high creativity are active, creative, curious, having good participation, and have their own spirit in exploring their ability for getting competency and skill. Because of their curiosity, they like to have a challenging activity to invent something new. They always have new idea and innovation to make greater achievement. Coulson in Rodriguez (2002: 23) states that high creativity students are those with a focus on the four stages of exploring, inventing, choosing and implementing creativity into the organization. He suggested that creativity and innovation are behaviors that have to be fostered throughout the organization by a measurable process in order to get results. It is undeniable that Content-based Instruction is more effective than Audiolingual Method and it is effective for students having high creativity because they are more challenged and interested to learn and practice their English. They can also explore their speaking skill because they have many opportunities to express their ability. Otherwise, The AudioLingual Method, or the Army Method is a style of teaching used in teaching foreign languages, that based on behaviourist theory. It is based on the theory that language learning is a question of habit formation. Since learning is thought to be a question of habit formation, errors are considered to be bad and to be avoided. New material is presented in dialogue form and there is dependence on mimicry, memorization of set phrase and structure patterns are taught using repetitive drills. It is supported by Brown (2001: 23), behaviouristic psychologist 
advocated conditioning and habitformation models of learning that were perfectly married with the mimicry drills and pattern practices of audio-lingual methodology. Further, teachers "reward" students by saying "Good!" and praising the class when they perform well. Students with low creativity will face some obstacles to speak well with good pronunciation, content, grammar, vocabulary, and fluency because they are not creative and need more stimulants to practice their English. Besides that, they are also shy if the teacher asks them to make a dialogue in front of the class because they have less motivation to study. They spent much time only to keep silent and face each other without producing any sound. They have nothing to do because they don't have innovation and can't develop their idea. Amabile et al (1996: 75) low creativity students are those having less motivation, stimulants and obstacles as a means for identifying the enabling and disabling forces to innovation and creativity. Based on the treatment of the research, using audiolingual method in teaching speaking is better than using Content-based Instruction for the students having low creativity because the students depend on drilling. That is why audio-lingual method is more effective than Content-based Instruction for the students having low creativity. Therefore, there is an interaction between teaching methods and students' creativity.

\section{Conclussions And Suggestions}

Based on the result of the data analysis, the research findings are as follows: (1) Content-based Instruction is more effective than Audio-lingual Method to teach speaking to the third semester students of STAIN Jurai Siwo Metro in the academic year of 2012/2013; (2) The students having high creativity have better speaking skill than those having low creativity of the third semester students of STAIN Jurai Siwo Metro in the academic year of 2012/2013; (3) There is an interaction between teaching methods and students' creativity in teaching speaking to the third semester students of STAIN Jurai Siwo Metro in the academic year of $2012 / 2013$. From the research findings, it can be concluded that Content-based Instruction is an effective method in teaching speaking for the third semester students of STAIN Jurai Siwo Metro in the academic year of 2012/2013. The effectiveness of the method is influenced by the students' creativity. Therefore, English teachers are expected to be able to select and use the appropriate teaching methods to teach speaking for the students having high and low creativity.

\section{References}

Amabile, Teressa M. 1996. Creativity and Innovation in Organization.Harvard Business School.

Arikunto, S. 2007. Prosedur Penelitian; Suatu Pendekatan Praktik $\left(6^{\text {th }}\right.$ Revised Ed.). Jakarta: P.T. Rineka Cipta.

Bailey, Kathleen M. (2005). Practical English Language Teaching: Speaking. New York. McGraw-Hill Companies, Inc.

Brown, H. Douglas. 2001. Principles of Language Learning and Teaching. San Francisco State University: Prentice Hall, Inc.

Brown, H. Douglas. 2007. Principles of Language Learning and Teaching. United States of America: Pearson Education

Dale, E., \& Chall, J. S. (1949). The concept of readability. Elementary English, 26, 19-26.

DuBay. H. William. 2004. The Principle of Readibility. California: Impact Information. Available at http//www.impactinformation.com 
Harmer, Jeremy. 2007. The Practice of English Language Teaching. Fourth edition. Edinburgh: Pearson education limited

Gay, L.R. 1992. Educational Research. Competencies for Analysis and Application New York: Macmilan Publishing Company.

Harmer, Jeremy. 2001. The Practice of English Language Teaching. 3rd Edition. Essex: Pearson Education Ltd.

Johnson, Burke and Christensen, Larry. 2000. Educational Research. Quantitative and Qualitative Approach. USA: A Pearson Education Company.

Nagaraj, G. 1995. English Language Teaching. Calcuta: Unique Accurates Private Ltd.

Richard, Jack C, 2006. Communicative Language Teaching Today, Cambridge University Press
Richard, Jack C, and Rodgers Thedore S. 2001. Approaches and Methods in Language Teaching, Second Edition. Melbourne: Cambridge University Press

Rodriguez, Susan Perkins. 2002. The impact of enabling creativity and innovation within the organization. New York University: Stern School of Business

Safertzi, Eleni. 2000. Creativity. INNERGIO: dissemination of innovation and knowledge management technique.

Stroller, F.L and Grabe William. 1997. A Six-T's Approach to ContentBasedInstruction. Retrieved on June, 5th. Available at http://Carla.umn.edu/cobaltt/modul es/curriculum/stroller_grabe

Sugiyono. 2010. Metode Penelitian Pendidikan. Bandung: Alfabeta 